\title{
Direct effect of parasitism by Dinarmus acutus Thomson on seed predation by Acanthoscelides perforatus (Horn) in Canada milk-vetch
}

\author{
A. BOE, B. MCDANIEL, AND K. ROBBINS
}

\begin{abstract}
Canada millk-vetch (Astragalus canadensis $L_{\text {.) }}$ is a widespread North American legume considered to be good forage in some regions but potentially dangerous to livestock when it contains high levels of 3-nitropropionic acid. Larvae of the seed predator Acanthoscelides perforatus (Hom) (Coleoptera:Bruchidae) occurred in $77 \%$ of the mature pods from 10 genotypes of the legume growing in a nursery at Brookings, S. Dak., in autumn 1987. Dinarmus acutus Thomson (Hymenoptera: Pteromalidae) parasitized $48 \%$ of the $A$. perforatus larvae and reduced numbers of seeds consumed by $A$. perforatus larvae by $23 \%$. This study identified $D$. acutus as a parasitoid of $A$. perforatus and indicated parasitoids may play an important role in recruitment of native lequmes.
\end{abstract}

Key Words: Astragahus canadensis L., Dinarmus acutus, Acanthoscelides perforatus, parasitold, seed predation

Canada milk-vetch (Astragalus canadensis L.) is the New World's most widely dispersed astragalus, ranging from the Gulf Coast in eastern Texas to the Appalachians and lower St. Lawrence River, west to the southern Rocky Mountains and the Great and Columbia Basins (Barneby 1964). It is perennial, rhizomatous, and usually quite robust. This legume is considered good forage in some regions (Hermann 1966), but can be toxic to livestock when it contains high levels of 3-nitroproprionic acid (James et al. 1980).

Bruchid beetles (Coleoptera:Bruchidae) are important seed predators of many North American legumes (Johnson 1970, Green and Palmbald 1975, Boe and Wynia 1985). The bruchid Acanthoscelides perforatus (Horn) has been reared from seeds of Canada milk-vetch (Johnson 1970), but its effects on seed production are unknown.

Lists of parasitoids of North American Bruchidae have been compiled (Cushman 1911, Johnson 1970, Center and Johnson 1975), but little is known about effects of parasitoids on population dynamics of North American legumes attacked by bruchid beetles.

Canada milk-vetch has forage and soil conservation potential, but evaluation for these purposes is dependent on adequate seed supplies of adapted ecotypes. Studies are needed to determine genetic, physical environment, and biotic influences on seed production. Objectives of this study were to quantify the effect of predation by $A$. perforatus on seed production of $C$. milk-vetch and determine parasitism rate of $A$. perforatus by the small wasp Dinarmus acutus Thomson (Hymenoptera: Pteromalidae) in a field nursery at Brookings, South Dakota.

\footnotetext{
Authors are associate professor, professor, and agricultural research technician. respectively, Plant Science Dep., South Dakota State Univ., Brookings 57007.

The authors extend their gratitude to Dr. C.D. Johnson, Northern Arizona Univ. for providing identification of Acanthoscelides perforatus; to Dr. E.E. Grisell, Systematic Entomology Laboratory, USDA, U.S. National Museum, Washington, D.C. for providing identification of Dinarmus acurus; and to Dr. R. Kieckhefer, Dr. G. Larson, and $\mathbf{R}$. Bortnem for critically reviewing the manuscript.

Contribution from the S. Dak. State Univ. Agric. Exp. Sta., Brookings, SD 57007. Journal Paper No. 2329.

Manuscript accepted 27 April 1989.
}

\section{Materials and Methods}

In July 1987, 4 inflorescences with mature pods were collected from each of 10 genotypes of Canada milk-vetch in a 250-spaceplant nursery establsihed on a Vienna loam, nearly level [fineloamy, mixed Udic Haploborolls] at Brookings, S. Dak., in May 1985. The seed source for the nursery was a vigorous population from a native prairie approximately $10 \mathrm{~km}$ northeast of Brookings, S. Dak. Inflorescences were placed in covered glass jars and maintained at room temperature. Adults of the hymenopterous parasitoid $D$. acutus began to emerge in large numbers from the pods in August 1987, but only a few adults of $A$. perforatus emerged during fall 1987. In January 1988, 30 random pods from each inflorescence of each genotype were carefully split along their septa, and the 2 locules of each pod were examined under a dissecting microscope at 10 to 30 magnifications.

Frequencies of pod infestations by $A$. perforatus and parasitism of $A$. perforatus by $D$. acutus were determined for 20 pods per inflorescence ( 80 pods per genotype). Unparasitized bruchidinfested locules contained a larva, pupa, adult or exit hole, and empty pupal case of $A$. perforatus. Parasitized bruchid-infested locules contained a larva, pupa, adult, or exit hole and exuviae of $D$. acutus, and the mummified remains of the parasitized bruchid larva.

The effect of parasitism by $D$. acutus on seed predation by $A$. perforatus was determined by counting intact seeds and testas of bruchid-destroyed seeds in unparasitized and parasitized bruchidinfested locules of a sample of 10 pods per inflorescence for 6 genotypes ( 40 pods per genotype). Analysis of variance was conducted on inflorescence means for percentage and number of intact seeds in locules infested by parasitized and unparasitized larvae of A. perforatus.

\section{Results and Discussion}

Seventy-seven percent of the pods of the 10 genotypes had at least 1 locule infested by $A$. perforatus and the overall mean percentage seed loss to bruchid predation was $44 \%$ (Table 1). These data showed $A$. perforatus can seriously reduce viable seed production in Canada milk-vetch. Green and Palmbald (1975) found seed predation by Acanthoscelides fraterculus (Horn) exceeded $60 \%$ in natural populations of Astragalus cibarius Sheld. and Astragalus utahensis (Torr.) T. and G., and postulated seed predation influenced population dynamics of these legumes.

Thirty-six percent of the pods contained insects in both locules, but multiple occupancies in locules were infrequent (only 3 locules contained 2 normal $A$. perforatus larvae). Since seed predation levels were high, cannibalism (Nelson and Johnson 1983) and/or competition (Boe et al. 1988) for food resources may have influ- 
Table 1. Pod infeatation and seed predation by the bruchid beetle $A$ canthoscelides perforatus in a nurery of Canada mills-vetch at Brookingh, South Dakota and the influence of paradtiem by Dinarmus acuthes on seed predation by the bectle.

\begin{tabular}{|c|c|c|c|c|}
\hline \multirow{2}{*}{$\begin{array}{l}\text { Infested }{ }^{3} \\
\text { pods }\end{array}$} & \multirow{2}{*}{$\begin{array}{l}\text { Overall seed }{ }^{2} \\
\text { predation }\end{array}$} & \multirow{2}{*}{$\begin{array}{c}\text { Parasitized }{ }^{3} \\
\text { beetles }\end{array}$} & \multicolumn{2}{|c|}{$\begin{array}{l}\text { Seed predation in infested } \\
\text { locules }\end{array}$} \\
\hline & & & Unparasitized & Parasitized \\
\hline & & $\%$ & & $67+17$ \\
\hline $77 \pm 144$ & $44 \pm 16$ & $48 \pm 24$ & $85 \pm 7$ & $62 \pm 17$ \\
\hline
\end{tabular}

IMeans sionificantly different at the 0.05 level.

${ }_{2}^{2}$ Means of 24 inflorescences; 10 pods per inflorescence.

'Means of 40 inflorescences; 20 pods per inflorescence.

¿Standard deviation.

enced larval survival.

Forty-eight percent of $A$. perforatus larvae were parasitized by $D$. acutus. $D$. acutus is found throughout the continental U.S. It has been reared from Bruchidius ater (Marsham) and Bruchus brachialis Fahr. (Krombein et al. 1979) and recorded from seed lots of legumes containing $A$. fraterculus and $A$. griseolus (Fall) (Johnson 1970), but $A$. perforatus is a new host record.

Seeds of Canada milk-vetch are small (approximately 1.5 $\mathrm{mg} / \mathrm{seed}$ ), and individual larvae of $A$. perforatus consumed the cotyledons, plumules, radicles, and parts of testas of 2 to 12 seeds. Unparasitized $A$. perforatus larvae destroyed $85 \%$ of the seeds in locules they infested compared to $62 \%$ when parasitized by $D$. acutus (Table 1). Uninfested locules contained $6.9 \pm 0.2$ intact seeds, and locules infested by parasitized beetles contained significantly $(P<0.05)$ more intact seeds $(2.6 \pm 0.2)$ than locules $(1.1 \pm$ 0.2 ) infested by unparasitized beetles. $D$. acutus had a direct influence on the present generation seed crop of Canada milk-vetch by reducing the number of seeds consumed by larvae of $A$. perforatus. Since normal larvae of the cabbage white butterfly (Pieris rapae (L.)) consumed more food than those parasitized by the solitary braconid parasitoid Apanteles rubecula Marsh (Rahman 1970), we speculate that parasitized bruchid larvae eat less than unparasitized larvae.

In large-seeded legumes in which 1 or more bruchid larvae feed and develop within a single seed (Johnson 1981), germinability and/or vigor are usually reduced due to extensive damage to the embryo (Boe et al. 1988). Although parasitism benefits largeseeded legumes by reducing the number of beetles that survive to reproduce, it will not increase the number of viable propagules from the present seed crop unless bruchid larvae are destroyed before they inflict severe seed damage.

The importance of parasitic Hymenoptera as biological controls of insect pests of cultivated crops is well-known, but their influence on recruitment and population dynamics of native legumes of North American rangelands and prairies has not been investigated. Many native legumes are important forage and soil conservation plants, while others are undesirable because of their toxicity to livestock (Cheeke and Shull 1985). This study identified D. acutus as a parasitoid of $\boldsymbol{A}$. perforatus and revealed its direct influence on the reproductive capacity of Canada milk-vetch. These findings suggest that elucidation of the interactions among native legumes, bruchid beetles, and parasitic Hymenoptera is critical to understanding the ecology and population dynamics of native rangeland legumes.

Seed predation levels in this space-plant nursery were comparable to those described for native stands of several other legumes. Legume seed predation by bruchid beetles may exceed 50\% (Green and Palmbald 1975, Boe and Wynia 1985) and occasionally reach nearly $100 \%$ (Rogers and Garrison 1975) in natural plant communities, but considerable variation occurs among years and locations (Baskin and Baskin 1977). Seed predation in 37 populations of American licorice (Glycyrrhiza lepidota Pursh) from North and South Dakota ranged from 7 to $71 \%$, with an overall mean of $41 \pm$ 2\% (Boe and Wynia 1985). The impact of bruchid beetles on long-term seed production and the efficacy of hymenopterous parasitoids for reducing seed losses in cultivated nurseries and seed increase fields of native legumes can only be determined after more extensive evaluation.

\section{Literature Cited}

Barneby, R.C. 1964. Atlas of North American Astragalus. Memoirs of the New York Botanical Garden Vol. 13. The New York Botanical Garden.

Baskin, J.M., and C.C. Baskin. 1977. Predation of Cassia marilandica seeds by Sennius abbreviatus (Coleoptera:Bruchidac). Bull. Torr. Bot. Club. 104:61-64.

Boe, A., and R. Wynia. 1985. Seed predation, seedling emergence, and rhizome characteristics of American licorice. J. Range Manage. 38:400-402.

Boe, A.B., B. MCDaniel, and K. Robbina. 1983. Patterns of American licorice seed predation by Acanthoscelides aureolus (Horn) (Coleoptera:Bruchidae) in South Dakota. J. Range Manage. 41:342-345.

Center, T.D., and C.D. Johnson. 1975. Host plants and parasites of some Arizona seed-feoding insects. Ann. Entomol. Soc. Amer. 69:195-201.

Cheeke, P.R., and L.R. Shull. 1985. Natural toxicants in feeds and poisonous plants. Avi Pub. Co., Inc. Westport, Conn.

Cushman, R.A. 1911. Notes on the host plants and parasites of some North American Bruchidae. J. Econ. Entomol. 4:489-509.

Green, T.W., and I.G. Palmbald. 1975. Effects of insect seed predators on Astragalus cibarius and Astragalus utahensis (Leguminosae). Ecology 56:1435-1440.

Hermann, F.J. 1966. Notes on western range forbs: Cruciferae through Compositae. USDA Agr. Handbk. 293.

James, L.F., W.J. Hartley, M.C. Williams, and K.R. Van Kampen. 1980. Field and experimental studies in cattle and sheep poisoned by nitrobearing Astragalus or their toxins. Amer. J. Vet. Res. 41:377-382.

Johnson, C.D. 1970. Biosystematics of the Arizona, California, and Oregon species of the seed beetle genus Acanthoscelides Schilsky (Coleoptera:Bruchidae). Univ. Calif. Pub. Entomol. 59:1-116.

Johnwon, C.D. 1981. Relations of Acanthoscelides with their plant hosts. In: V. Labeyrie (ed.), The ecology of bruchids attacking legumes (pulses). Dr. W. Junk Pub., The Hague.

Krombein, K.V., P.D. Hurd, D.R. Smith, B.D. Burks, et. al. 1979. Catalog of Hymenoptera in America north of Mexico. Washington: Smithsonian Institution Press. Vol. 1:Symphyta and Apocrita (Parasitica), xvi + $1-1198$.

Nelson, D.M., and C.D. Johnson. 1983. Selenium in seeds of Astragalus (Leguminosae) and its effects on host preferences of bruchid beetles. J. Kans. Entomol. Soc. 56:267-272.

Rahman, M. 1970. Effect of parasitism on food consumption of Pieris rapae larvae. J. Econ. Entomol. 63:820-821.

Rogers, C.E., and J.C. Garrison. 1975. Seed destruction in indigobush Amorpha by a seed beetle. J. Range Manage. 28:241-242. 